\title{
An Analysis of Factors Influencing Income of Households Producing Lychee Bearing Geographical Indications in VIETNAM
}

\author{
Dr. Nguyen Quang Hau \\ Hoa Binh University, Viet Nam \\ Dr. Le Thi Yen \\ Thai Nguyen University of Economics and Business Administration, Vietnam
}

\begin{abstract}
This study was conducted to analyze the factors influencing the income of households producing products bearing geographical indications in Vietnam. Data for the study were collected from a survey of 188 households growing lychee bearing geographical indications in Vietnam. Using OLS regression model to analyze the infulence level of factors. Research findings show that, the number of household labor, selling price, investment capital ....Factors affecting the income of households producing lychee products bearing geographical indications in Vietnam. Research findings are used as a basis for proposing recommendations to improve the income of households producing lychee with geographical indications in Vietnam.
\end{abstract}

Keywords: Income, production households, lychee, GIs.

\section{Introduction}

Vietnam is a country which have a agriculture commodities diversity and to be favoured by nature with the development of products along with the quality of products, it has contributed to promoting the general economic development of Vietnam.

However, besides the achievements, agriculture still exists and limited: the forms of organization of production is slow to reform; agricultural production in many places is still fragmented, lack of links; rural environmental pollution in many places is still serious; life of a part of people, especially in remote areas still difficult; food safety and hygiene is still a pressing issue; unsustainable agricultural and rural industries, difficulties in the context of international economic integration

In that context, agricultural development orientation needs to take into account the appropriate access strategies, focusing on two main development axes:1) production and market access for agricultural products in large numbers and popularity, applied science and technology, advantages in large-scale goods producing ; 2) produce and access markets with traditional, specialty products, quality and high added value based on regional advantages, cultural traditions and the accumulation of skills of the people. Along with each orientation are different 
solutions that can promote commercial development, use appropriate measures for the protection of intellectual property to support the sustainable development of agricultural commodities

Vietnam has focused on developing strategic product bearing the geographical indication as a solution to build a brand for agricultural products, improve the value and effectiveness of agricultural production, as of December 30, 2016, Vietnam has protected 48 geographical indications, including 4 geographical indications of foreign countries and 44 geographical indications of Vietnam

Lychee bearing geographical indications is one of Vietnam's typical agricultural products, local people have the main source of income from this tree. Therefore, how to develop this product to increase the income of people is a question that must be solved not only by policy makers, researchers but also the research object is the producer of these products. Therefore, this study was conducted to analyze the factors influencing income of households producing lychee bearing geographical indications in vietnam.

\section{Overview of research}

The influencing of factors on income of households has been approached under different view, specifically:

Dominique Barjolle et al (2009) focused on methods to assess the impact of territorial geographical indications (economic, social and environmental), the results show that economic benefits are is the only engine in implementing product protection projects with geographical indications. The results show that these economic benefits is only purpose in implementing product protection projects with geographical indications.

Or in view of the Carina Folkeson (2005) the authors consider the economic impact of the geographical indication to object is the manufacturer. The research findings also show that the production of products bearing geographical indications in the EU has in many cases contributed to rural development, although the development is different between regions and different products. The study also concluded that statutory protection is necessary for benefits arising from the production geographical indications to benefit producers and related actors. The research results show that Basmati rice is more profitable than other crops, after that, the author studies the factors affecting the decision to produce products bearing geographical indications, one of the number of factors mentioned is the ability to access policies and the number of workers in the household.

Pradyot R. Jena, Ulrike Grote, (2010) used data from a survey of 300 rice farmers in a province of northern Indian namely Uttarakhand. In the study, the author analyzes the total profit, determines the net benefits of Basmati rice bearing geographic indications with other plants in the same locality but does not have a production certificate with specific geographical indications. The author chooses crop that do not have geographic indications certification as sugarcane....Simultaneously, the author has used the marginal benefit analysis method as a basis for conducting this research, straight line regression (OLS) used by the author to analyze the impact of geographical indications.

Le Dinh Thang (1993), Nguyen Sinh Cuc (2001) in their research, there were opinions about production households, each study has different specific views about production households, but in common, it is agreed that production households are units which participate in the production of mining activities, processing products related to agriculture.

Some other studies conducted to determine the factors affecting the income of households in 
specific areas, in different localities such as: Nguyen Quoc Nghi et al (2011), Nguyen Van Thieu et al (2011), Nguyen Van Toan et al (2012), Huynh Thi Dan Xuan (2012), Nguyen Thi Hong Hanh et al (2013) ...Primary data is also selected by the authors for their research, this is also the most obvious similarity to the studies related to considering factors affecting household incomes, specifically here are the farm households agricultural production studied by the authors. The purpose of the studies: to determine the average income of households, and the factors affecting household income, the relationship between them. With the data collected, the author conducted the analysis using descriptive modeling and statistical methods, the models used were OLS models, this is a model which is relatively popular with research in Vietnam regarding factors affecting household's income in different fields

\section{Research Methodology}

\subsection{Data collection methods}

Data information serves for statistical analysis in this chapter was collected from the research team interviewed householdsby using standardized questionnaires.

Time for survey: From January 2018 to the end of May 2018.

+) Number of samples:

There are many different concepts about the sample, according to Hoelter (1983), the critical sample size must be 200.Nunnally and Burnstein (1994) suggest that with the Maximum Likelihood (ML) estimation method, the sample size must be at least 100-150.

From Nguyen Van Thang's point of view (2014), the minimum number of samples that can perform statistical operations is 100 .

Accordingly, the authors conducted a survey after cleaning ensures data and minimum number of samples collected to perform statistical calculations of 100 observations for the study

The author conducted a survey with 300 representatives of households. After collecting survey questionnaires, input data into excel software, the author removes the survey forms that do not meet the requirements of data for the research, retains the completed questionnaires to request information to perform statistical analysis. 188 surveys were clean and meet the performance requirements of statistical analysis, the authors used observations performed 188 analyzes for the study, number of observations meet the requirements for the minimum number of observations to study the implementation of statistical analysis

\subsection{Data analysis methods}

Data after being collected will be imported into exel software, then with the help of SPSS20.0 software, the author performs OLS regression to analyze the infulence level of factors to the income of households producing lychee products bearing geographical indications.

\section{Finding}

The author regresses the model to assess the influence of some factors on the income of households producing lychee products bearing geographical indications as follows:

*) Check the relevance of the model

With the proposed research model, the author conducts the verification of the appropriateness of regression form and some model defects.

Specific test results: 
Table 1: Results of conformity testing and some model defects

\begin{tabular}{|c|c|c|c|c|c|c|c|c|c|c|}
\hline \multicolumn{11}{|c|}{ Model Summaryb } \\
\hline \multirow[b]{2}{*}{ Mode } & \multirow[b]{2}{*}{$\mathrm{R}$} & \multirow{2}{*}{$\begin{array}{c}\mathrm{R} \\
\text { Square }\end{array}$} & \multirow{2}{*}{$\begin{array}{l}\text { Adjusted } \\
\text { R Square }\end{array}$} & \multirow{2}{*}{$\begin{array}{c}\text { Std. Error } \\
\text { of the } \\
\text { Estimate }\end{array}$} & \multicolumn{5}{|c|}{ Change Statistics } & \multirow{2}{*}{$\begin{array}{l}\text { Durbin- } \\
\text { Watson }\end{array}$} \\
\hline & & & & & \begin{tabular}{|l|} 
R Square \\
Change
\end{tabular} & F Change & df1 & df2 & $\begin{array}{c}\text { Sig. F } \\
\text { Change }\end{array}$ & \\
\hline 1 & $.886^{a}$ & .785 & .780 & 46.284 & .785 & 166.792 & 4 & 183 & .000 & 2.024 \\
\hline
\end{tabular}

Source: Analysis results from the author's research data

With R Square coefficient $=0.785$ indicates that the independent variables in the model explain $78.5 \%$ of the dependent variable.

The test results show that the author model is relatively good when there is no defect in autocorrelation in the model, and the independent variables explain $78.5 \%$ of the dependent variable.

Table 2: Results of conformity testing and some model defects

\begin{tabular}{|c|c|c|c|c|c|c|}
\hline \multicolumn{7}{|c|}{ ANOVA $^{a}$} \\
\hline & Model & Sum of Squares & Df & Mean Square & F & Sig. \\
\hline \multirow{3}{*}{1} & Regression & 1429238.675 & 4 & 357309.669 & 166.792 & $.000^{\mathrm{b}}$ \\
\hline & Residual & 392032.198 & 183 & 2142.252 & & \\
\hline & Total & 1821270.872 & 187 & & & \\
\hline \multicolumn{7}{|c|}{ a. Dependent Variable: Thu_nhap } \\
\hline
\end{tabular}

Source: Analysis results from the author's research data

Results from table 2 show:

+ ) With Sig coefficient $=0.000$; test $F=166,792$, so the research linear regression model is appropriate.

From data collected through the interview process ..., combined with the help of SPSS 20.0 software. The author uses the least squares method to consider the influence of factors on the income of households producing lychee products bearing geographical indications:

Table 3: Results of Regression model

\begin{tabular}{|l|c|c|c|c|c|}
\hline \multicolumn{5}{|c|}{ Coefficients $^{\mathrm{a}}$} \\
\hline \multirow{2}{*}{ Model } & \multicolumn{2}{|c|}{ Unstandardized Coefficients } & $\begin{array}{c}\text { Standardized } \\
\text { Coefficients }\end{array}$ & $\mathrm{t}$ & Sig. \\
\cline { 2 - 4 } & $\mathrm{B}$ & Std. Error & Beta & & \\
\hline
\end{tabular}




\begin{tabular}{|c|l|c|c|c|c|c|}
\hline \multirow{3}{*}{1} & (Constant) & 88.158 & 15.158 & & 5.816 & .000 \\
\cline { 2 - 7 } & Hoc_van & -2.454 & 1.131 & -.075 & -2.170 & .031 \\
\cline { 2 - 7 } & SL_LD & 9.880 & 1.099 & .362 & 8.992 & .000 \\
\cline { 2 - 7 } & Gia_ban & 6.153 & .940 & .495 & 6.548 & .000 \\
\cline { 2 - 7 } & Quy_mo_von & .209 & .094 & .163 & 2.215 & .028 \\
\hline \multicolumn{2}{l}{ a. Dependent Variable: Thu_nhap }
\end{tabular}

Source: Analysis results from the author's research data

Through the table results in the factors,

Group of factors affecting the same direction to income include: number of workers in the household, selling price and investment capital. In which, the factor of number of employees in households seems to affect most on average income of households with a coefficient of 9.880 . Group of factors negative effect to the average income: the education level of the household head, the coefficient of this variable is negative. Specifically, how each of these factors affect the average income of households producing lychee products analyzed by the author below:

+) Number of workers in the household:

The factor of number of household workers positively affects the income of households producing lychee products, the coefficient of this variable is 9.880 with $99 \%$ significance level (sig. $=0.001<0.01$ ). Specifically, when the number of workers in the household increases by 1 , the average income of households producing lychee products increases by $9.880 \%$ (according to the standardized beta coefficient)

This result is consistent with the viewpoint: Under less mechanized production conditions, the number of employees will be a key factor to increase household income of Abdulai\&CroleRees, 2001; Yang, 2004. For producing lychee products is an agricultural product, labor is an essential element because the steps from care to collection need to be used for labor such as: pruning trees when the season ends clean the leaves, soil improvement, clean the weeds under the trees and collecting the entire crop residues on the focal point for limiting pest refuges, ... Therefore, a lot of workers will help create better care for the garden, improve the productivity of lychee

+) Price:

Research results show that the selling price factor positively affects the income of households producing lychee products, the coefficient of this variable is 6.153 with a $99 \%$ significance level (sig. $=0,000<0.05)$. Specifically, when the price increases by 1 , the average income of households producing lychee products increases $6.153 \%$ (according to the standardized beta coefficient).

The selling price of products relatively large impact to household income producing products with geographical indications, if the price is not stable, At the beginning and at the end of crop, the price is high, at the main crop the lychee 's price is low, the price difference between Luc Ngan lychee area with other districts in the province or with other provinces does not lead to insecure income for farmers.

+) Investment capital:

The factor of investment capital has the same impact to the income of households producing lychee products, the coefficient of this variable is 0.209 at the $95 \%$ significance level (sig. $=0.028$ $<0.01$ ). Specifically, when the investment capital of households increases by 1 , the average 
income of households producing lychee products increases by $0.209 \%$ (according to the standardized beta coefficient).

One of the important factors in production and business is a must stable capital, capital needed for new technology application, fertilizer purchase as well as labor cost ... When lychee products are bought by customers and the demand increases, business households tend to improve or expand their land, however, for this product, it requires long-term investment to improve the quality as well as productivity,

Because this is a seasonal product, only once a year, so to invest in renovating or growing it takes a lot of time and effort. Investment capital can be obtained from equity or credit.

However, the equity of the households is only enough to cover a part of the costs, the remaining investment capital is mainly borrowed from credit, so the loan is very important for the households. When households are supported with good loans, business households have capital to invest in machinery, technology, expand production, income will increase. This result is consistent with the research of Huynh Thi Dan Xuan and Mai Van Nam (2011), Nguyen Quoc Nghi et al (2011).

+) Education level:

The research results show that the educational level has a negative impact on the income of households producing lychee products, the coefficient of this variable is -2.454 with the significance level of $95 \%$ (sig. $=0.031<0.01$ ). Specifically, when the education level increased by 1 , the average income of households producing lychee products decreased $0.424 \%$ (according to the standardized beta coefficient)

This result is the opposite with the views of Foster \&Rosenzweig, 1996; Pitt \&Sumodiningrat, 1991; Yang, 2004: education determines the advantages of each person in creating income by high education that is receptive, apply new techniques to production and efficient use of other resources. Besides, education also enhances the ability to capture and process market information to create opportunities to participate in non-farm activities, thereby increasing income. And also does not support the views of author Nguyen Quoc Nghi et al (2011), The education level of the household head is positively related to household income, meaning that the higher the education level, the more income the people have

However, as analyzed, lychee products are agricultural products and have been on the market for many years, not a new product. It is also a reason that the education level has no positive impact on income. The most important agricultural work is experience, "experience is better than cleverness", especially with lychee fruit, farmers need to have practical knowledge to deal with plant diseases, which season should fertilize fertilizer, which period should spray pesticides and growth regulators suitable for lychee...High level of education, a lot of knowledge but rarely practice, rarely working when embarking on to practice is embarrassing, inexperienced leading to failure.

\section{Conclusion}

This research was conducted to analyze factors influencing income of households producing lychee bearing geographical indications in VietNam. The research findings are the foundation for helping policy makers to use as a base to proposed policy recommendations for the country, local to develop products with geographical indications. At the same time, research is also useful reference works for students in economic majors which can be used for reference. However, in the future, if it is possible expand the scope of the study with other products bearing geographical indications, Research findings will be better. 


\section{Recommendations}

To increase the income of lychee farmers bearing geographical indications in Vietnam, some proposed solutions are as follows:

Training courses on processing and preserving lychee products need to be organized from which can choose a wider range of product consumption methods more diverse for producers.

Training for households producing/ farmers who growing agricultural products about market development skills

When skilled in market development and exposure to customer needs for products, producers will know what customer requirements about their products and will adjust to suit the tastes and meet market demand: including in both quality as well as requirements when packaging and harvesting products.

Strengthening support from competent state agencies to support people in credit loans, market access, rational use of resources in production and business of households, lychee growers to avoid input resource wasting.

\section{References}

Carina Folkeson, (2005), Geographical Indications and Rural Development in the EU, school of economics and management, Lund University

Dominique Barjolle, Marguerite Paus, Anna Perret, (2009), Impacts of Geographical Indications Review of Methods and Empirical Evidence, International Association of Agricultural Economists Conference, Beijing, China

Huynh Thi Dan Xuan and colleagues, (2011), Analysis of factors affecting the income of poultry farms in the Mekong Delta, Science Journal - Can Tho University

Hoang Trong and Chu Nguyen Mong Ngoc, (2008), Statistics in socio-economy, Statistical Publishing House

Le Dinh Thang ,(1993), Household economic development toward commodity production, Agricultural Publishing House, Hanoi

Nguyen Sinh Cuc ,(2001), rural survey analysis in 2000.

Nguyen Thi Hong Hanh and colleagues, (2013), the impact of withdrawing agricultural land on lives of farmers in Van Lam district, Hung Yen province. Scientific journals and development No. 1, episode 11

Nguyen Dinh Tho et al, (2012), Methods of scientific research in business: Design and implementation, Labor and Social Publishing House.

Nguyen Van Thang, (2014), research practices in economics and business administration course, National Economics University Publishing House

Nguyen Quoc Nghi et al, (2011), Factors affecting income of ethnic minorities in the Mekong Delta, scientific journal vol 18

Nguyen Quoc Nghi, (2011), Accessibility official capital of poor households. Banking Magazine, No. 7, 2011 
Journal of Management and Economic Studies, vol.1, issue.7, pp.32-39

Nguyen Van Thieu et al (2014), Factors affecting livelihoods and sustainable livelihood solutions for people in flooded areas in An Giang province.

Pradyot R. Jena, Ulrike Grot, (2010), does geographical indication (GI) increase producer walfare? A case study of Basmati rice in Northern India, the ISEE conference

Vu Thi Minh ,(2004), Developing fruit trees in mountainous areas of Quang Ninh province, National Economic University

Nguyen Van Toan, (2012), Effects of P135 programs on the livelihoods of ethnic minorities in Huong Hoa district, Quang Tri province, science Journal- Hue University 3 episode number $72 \mathrm{~B}$.

Tabachnick, B.G., \& Fidell, L. S, (2007), Using multivariate statistics (3rded.), New York: Harper Collins 